\title{
Hormonal Profile and Reproductive Parameters of Pre-vitellogenic Mozambique tilapia (Oreochromis mossambicus) on Pawpaw (Carica papaya) Seed Meal
}

\author{
Victor Okonkwo Omeje ${ }^{1,2}$, Helet Lambrechts ${ }^{1} \&$ Danie Brink $^{3}$ \\ ${ }^{1}$ Department of Animal Sciences, Stellenbosch University, Matieland, South Africa \\ ${ }^{2}$ Department of Veterinary Medicine, University of Nigeria, Nsukka, Nigeria \\ ${ }^{3}$ Department of Genetics, Stellenbosch University, Matieland, South Africa \\ Correspondence: Victor Okonkwo Omeje, Department of Veterinary Medicine, University of Nigeria, Nsukka, \\ Nigeria. E-mail: okonkwo.omeje@unn.edu.ng
}

Received: August 18, 2018

Accepted: November 5, 2018 Online Published: January 15, 2019

doi:10.5539/jas.v11n2p524

URL: https://doi.org/10.5539/jas.v11n2p524

\begin{abstract}
The use of phytochemicals to control precocious maturation and indiscriminate spawning among tilapia species is an important issue in aquaculture. This study investigated the influence of pawpaw (Carica papaya) seed meal on the reproductive performance, and the sex hormone profile of sexually immature Mozambique tilapia (Oreochromis mossambicus). Pawpaw seed meal (PSM) were included in a tilapia commercial diet (basal diet) at an inclusion level of 0 PSM, 10 PSM and 30 PSM g/kg of the basal diet (BD), respectively, and fed to immature O. mossambicus for a period of 30 and 60 days, respectively. Enzyme-linked immune-sorbent assay (ELISA) procedures were used to quantify the plasma levels of $17 \beta$-estradiol and 11-ketotestosterone. The inclusion of PSM did not affect the growth and survival rate of the O. mossambicus. The plasma levels of 11-ketotestosterone did not differ among the treatment groups. The $17 \beta$-estradiol levels of female fish that received $30 \mathrm{PSM} \mathrm{g} / \mathrm{kg} \mathrm{BD}$ for 60 days were significantly lower $(\mathrm{p}<0.05)$ than the levels reported for females that were not fed the PSM. In females, the PSM reduced the gonad weight, GSI, fecundity and egg diameter of fish. The study concludes that pawpaw seed meal affected the reproductive function of the female O. mossambicus though the changes were reversible.
\end{abstract}

Keywords: Carica papaya, estradiol, gonadosomatic index, keto-testosterone, phytochemical, tilapia

\section{Introduction}

Phytochemicals from different plants have been credited with antibacterial, antifungal, pesticidal and molluscicidal activities (Jaiswal \& Singh, 2008; Maranho et al., 2014). Carica papaya (Linn. Caricaceae), commonly known as pawpaw, is an important food plant that is cultivated worldwide. Apart from its nutritious fruit, different parts of the plant have been used extensively for medicinal purposes. Pawpaw seeds were reported to cause a reduction in fecundity, hatchability, egg size and gonado-somatic index in fish (Hossam \& Wafaa, 2011). Mozambique tilapia (Oreochromis mossambicus) is one of the important members of the tilapia family (Coward \& Bromage, 2000) and like other members of the family, it is very prolific both in the wild and in captivity. The prolific nature of the species is considered as the greatest hindrance to profitable culture due to the fact that precocious breeding result in a large proportion of the fish in culture systems being unmarketable, due to a large proportion of the fish being too small to contribute to optimal production. To overcome the problems of stunted growth occasioned by indiscriminate spawning in mixed tilapia culture, several methods have been used to produce mono-sex tilapia culture systems, the most common amongst them is the use of hormones to manipulate the gender of treated fish (Desprez et al., 2003). Sex reversal in fish is also practiced because of the belief that a particular gender has a growth advantage over the other which in the case of tilapia, males grows faster than females (Lovshina et al., 1990).

Because of the disadvantages inherent in the use of hormones to manipulate the gender of fish, which include amongst others the cost of the hormones, health hazard to workers, adverse environmental effects and unfavourable public perception of the use of hormone in food fish production (Beardmore et al., 2001), scientists have investigated the potential to use less harmful phytochemicals of plant origin like Moringa (Moringa oleifera) 
and pawpaw seed meal to manipulate the gender in fish (Ampofo-Yeboah, 2013). Phytoestrogens are referred to as endocrine disrupting compounds, and are capable of causing reproductive dysfunction in animals including fish (Clotfelter \& Rodriguez, 2006; Bahrami Babahydari et al., 2014). Some phytochemicals are believed to be estrogenic in nature, which means they either mimic the action of oestrogen or they compete for oestrogen receptors, thereby blocking the action of natural oestrogens (Rearick et al., 2014).

Follicle stimulating hormone (FSH) and luteinizing hormone (LH) stimulate the synthesis and secretion of the androgen and estrogen. Estradiol $17 \beta$ is responsible for the development of oogonia and vitellogenesis in females, and androgen is responsible for spermatogenesis in males (Yaron \& Levavi-Sivan, 2011). Scientists believe that the rate of secretion of hormones from the pituitary and gonads and the rate of clearance determines the eventual concentration in the blood (Cornish, 1998). Exogenous compounds that interferes with the endogenous hormone reception is termed endocrine disrupting compounds (Casanova-Nakayama et al., 2011). Changes in reproductive parameters such as fecundity, gonado-somatic index and sex steroid hormones; $17 \beta$-estradiol and 11-ketotestosterone concentration in plasma can be used as an endpoint indicators of endocrine disrupting chemicals in fish (Dang et al., 2011). As there is little information available on the influence of pawpaw seeds on the reproductive hormones of $O$. mossambicus, the present study was aimed to evaluate the effect of the phytochemicals contained in the seeds of the plant on the reproductive hormone profile and other reproductive parameters of the fish in greater depth.

\section{Materials and Methods}

\subsection{Experimental Location and Facilities}

The experiment was conducted in a plastic water re-circulatory system at the Aquaculture unit of the Welgavellen experimental farm of the University of Stellenbosch, South Africa. The plastic tanks have a dimension of $40 \times 70 \times 38 \mathrm{~cm}(\mathrm{~L} \times \mathrm{W} \times \mathrm{H})$ and volume of $90 \mathrm{~L}$. The physicochemical parameters of the culture water were monitored daily. A digital YSI ProODO (Model: EC300, YSI Inc., Yellow Springs, USA) was used to monitor the dissolved oxygen, temperature and conductivity while Crison ICR12502 $\mathrm{pH}$ meter (HACH, USA) was used to monitor the $\mathrm{pH}$. The mean water temperature recorded was $26.03 \pm 0.61{ }^{\circ} \mathrm{C}$, dissolved oxygen was $6.77 \pm 0.78 \mathrm{mg} / \mathrm{l}$ while $\mathrm{pH}$ and conductivity were $6.42 \pm 0.18$ and $210 \pm 8.02 \mu \mathrm{S} / \mathrm{cm}$ respectively.

\subsection{Experimental Animals and Diets}

A total of 1000 two months old juvenile $O$. mossambicus (mean weight $24.81 \pm 8.54 \mathrm{~g}$, mean total and standard lengths of $11.06 \pm 1.3 \mathrm{~cm}$ and $8.84 \pm 1.14 \mathrm{~cm}$, respectively) were used for the study of the effect of pawpaw seed meal on the reproductive parameters and hormonal profile of the fish. The fish were obtained from the Rivendell hatchery, Grahamstown South Africa and were acclimatized for three weeks. During the acclimatization period they were fed ad libitum twice daily with a standard (basal) tilapia commercial diet. Ingredient composition of the basal diet according to the production company (Aqua-Nutro, Nutroscience (Pty) Ltd, Malmesbury, South Africa) include; protein $400 \mathrm{~g} / \mathrm{kg}$; lipid $80 \mathrm{~g} / \mathrm{kg}$; moisture $120 \mathrm{~g} / \mathrm{kg}$; fibre $40 \mathrm{~g} / \mathrm{kg}$; calcium $30 \mathrm{~g} / \mathrm{kg}$ and phosphorus $7 \mathrm{~g} / \mathrm{kg}$. Prior to the commencement of the experiment, the entire fish were sexed with the aid of hand lens and the male to female (M: F) sex ratio obtained was 1:0.9.

Fresh seeds were obtained from large quantities of ripe pawpaw obtained from fruit vendors in Stellenbosch, Western Cape, and dried in-doors. The dried seeds were blended to a fine powder using a laboratory grinder (Knifeter 1095, FOSS Tecator, Hoganas, Sweden), and stored in Ziploc bags for later use. The standard (basal) diet consisted of a tilapia commercial diet ( $40 \%$ crude protein). The pawpaw seed meal (PSM) was added to the basal diet according to the inclusion level for the treatment groups, mixed thoroughly in Macadams baking system (model: SM-401; Cape Town, South Africa), pelleted in an extruder and oven-dried in a CFW Envirowatch 5 (model: Ǿ560; Cape Town, South Africa) and then stored in airtight containers for later use.

\subsection{Experimental Design}

The experimental set up based on the inclusion levels and duration of the feeding period of the experimental diet was as follows:

Basal diet (BD) with no inclusion of PSM fed for 60 days was designated as P0M2 (Control), inclusion of $10 \mathrm{~g}$ $\mathrm{PSM} / \mathrm{kg}$ BD fed for the first 1 month (30 days) was designated as P10M1, inclusion of $30 \mathrm{~g} \mathrm{PSM} / \mathrm{kg}$ BD fed for the first 1 month (30 days) was designated as P30M1. Also inclusion of $10 \mathrm{~g} \mathrm{PSM} / \mathrm{kg}$ BD fed for 2 months (60 days) was designated as P10M2 while inclusion of $30 \mathrm{~g}$ PSM $/ \mathrm{kg}$ BD fed for 2 months (60 days) was designated as P30M2. There were five experimental treatment groups with four replicates each with stocking density of 50 fish per replicate. The fish were fed ad libitum three times a day $(9.00,13.00$ and $17.00 \mathrm{~h})$ with the experimental diets. The waste and uneaten food in the aquaria were carefully removed daily by siphoning and the tanks 
refilled with fresh water. Dead fish were removed from culture tanks immediately. On the day of stocking, all fish were weighed individually and their total and standard lengths measured. Taking the weight, total and standard lengths of the entire experimental fish were repeated on the $30^{\text {th }}$ and $60^{\text {th }}$ days of the study. The total and standard lengths of the specimen were measured using a measuring board graduated in centimeters. Top loading balance (Electronic Balance, UWE, HGS-300, capacity: $300 \times 0.01 \mathrm{~g}$, Serial \# P9440) was used to measure the body weight of the fish samples to the nearest grams. At the end of 60 days experimental period, twenty fish from each replicate (ten males and ten females) were randomly selected and after taking their weights, dissected to ascertain the maturation of the gonads, fecundity, and egg diameter and the gonado-somatic index calculated. The diameter of 12 eggs randomly taken from the anterior, middle and posterior parts of the ovary was measured using a binocular microscope. The long and short axis of each egg were measured and the mean taken as the diameter of the egg (Abdelhak et al., 2013).

Specific growth rate was calculated using the formula:

$$
\mathrm{SGR}=\frac{\mathrm{LnW}_{\mathrm{f}}-\mathrm{LnW}_{\mathrm{i}}}{\mathrm{T}(\text { days })} \times 100
$$

Where, $\mathrm{W}_{\mathrm{f}}=$ final weight and $\mathrm{W}_{\mathrm{i}}=$ initial weight.

Dissected ovaries were preserved in buffered $10 \%$ formalin for 3 weeks, later they were gently agitated to separate the eggs from the ovarian tissues and then the formalin decanted out. The eggs were washed by adding clean water in a beaker containing the eggs, after gentle agitation, the water was filtered out. Entire eggs were put in a clean filter paper and weighed, a sub-sample of the eggs were weighed then counted. The fecundity of each female fish sampled was determined using the formula:

$$
\text { Fecundity }=\frac{\text { Total weight of ovary }}{\text { Weight of sub sample }} \times \text { Number of mature eggs in sub sample }
$$

Gonado-somatic index (GSI) was determined using the formula:

\subsection{Determination of Steroid Hormone Level}

$$
\mathrm{GSI}=\frac{\text { Gonad weight }(\mathrm{g})}{\text { Total body weight }(\mathrm{g})} \times 100
$$

Blood samples were collected from twenty fish (ten males and ten females) from each replicate on Day 0 of the experiment from the caudal circulation with the aid of $3 \mathrm{ml}$ disposable plastic syringes and a 21 gauge needle. The collected blood was put into $2 \mathrm{ml}$ (purple coloured cap) ethylene diamine tetra acetic acid (EDTA) vacutainer tubes. The plasma was collected by centrifugation at $3500 \mathrm{rpm}$ for 10 minutes at $4{ }^{\circ} \mathrm{C}$ using Eppendorf centrifuge (Model 5804R). The plasma was pipetted out of the sediment and put in Eppendorf tubes (200 $\mu \mathrm{L}$ of plasma in each tube) and stored in the freezer at a temperature of $-20{ }^{\circ} \mathrm{C}$ until analysed. Blood samples were again collected on Day 30 and Day 60 of the experiment. The reproductive hormones, $17 \beta$-estradiol and 11-ketotestosterone were quantified using ELISA kits specific for the quantitation of fish hormones. The 11-ketotestosterone hormone was assayed using fish specific 11-ketotestosterone EIA kit (Item №: 582751; Batch: 0468795) manufactured by Cayman Chemical, USA while 17ß-estradiol was assayed using Fish Estradiol (E2) ELISA kit (Catalog №: CSB-E13017fh; Lot: C2489421809) manufactured by CUSABIO BIOTECH Co, China. The procedures for the assays were according to manufacturer's instruction and were done in duplicate.

\subsection{Statistical Analysis}

Kolmogorov Smirnov's test was used to estimate normality of data and homogeneity of variance was assessed with Levene's test. Based on these tests, all data were found to be normally distributed. The results are presented as means $\pm \mathrm{SE}$. The data were analysed by one way analysis of variance (ANOVA), with confidence interval of 95\%. Variant means were separated by using Bonferroni (Dunn) $t$ test. Statistical analysis was performed using the XLSTAT software program (version: 2015.2.02.18165).

\section{Results}

\subsection{Morphometric Parameters}

Results of the morphometric parameters measured on the $60^{\text {th }}$ day of the feeding trial indicated no significant difference $(\mathrm{P}>0.05)$ among groups. The mean total lengths ranged between $13.64 \pm 0.17 \mathrm{~cm}(\mathrm{P} 30 \mathrm{M} 2)$ and $13.93 \pm 0.17 \mathrm{~cm}$ (P10M1) while mean standard lengths ranged between $10.71 \pm 0.14 \mathrm{~cm}(\mathrm{P} 30 \mathrm{M} 1)$ and $11.21 \pm 0.14$ $\mathrm{cm}$ (P10M2). Also mean weights ranged between 44.24 $\pm 1.72 \mathrm{~g}$ (P30M2) and 48.36 $\pm 1.72 \mathrm{~g}$ (P10M2). Furthermore, the mean specific growth rate (SGR) ranged between $0.96 \pm 0.07$ (P0M2) and $1.11 \pm 0.07$ (P10M2). 
The SGR also indicated no significant difference $(\mathrm{P}>0.05)$ between different groups. There were high survival rate in all the treatment groups ranging between $96.5-97.5 \%$ (Table 1 ).

Table 1. Morphometric parameters (mean $\pm \mathrm{SE}$ ), specific growth rate and survival rate of $O$. mossambicus fed diets containing pawpaw seed meal for 30 and 60 days

\begin{tabular}{llllll}
\hline Treatment & Total length $(\mathbf{c m})$ & Standard length $(\mathbf{c m})$ & Final Weight $(\mathbf{g})$ & Specific growth rate & Survival rate (\%) \\
\hline P0M2 (Control) & $13.75 \pm 0.17$ & $10.8 \pm 0.14$ & $44.56 \pm 1.72$ & $0.96 \pm 0.07$ & 97.5 \\
P10M1 & $13.82 \pm 0.17$ & $10.86 \pm 14$ & $46.25 \pm 1.72$ & $1.04 \pm 0.07$ & 96.5 \\
P30M1 & $13.65 \pm 0.17$ & $11.1 \pm 0.14$ & $45.7 \pm 1.72$ & 1.030 .07 & 96.5 \\
P10M2 & $13.93 \pm 0.17$ & $11.21 \pm 0.14$ & $48.36 \pm 1.72$ & $1.11 \pm 0.07$ & 97 \\
P30M2 & $13.64 \pm 0.17$ & $10.71 \pm 0.14$ & $44.24 \pm 1.72$ & $1.0 \pm 0.07$ & 96.5 \\
\hline
\end{tabular}

\subsection{The Influence of PSM on 17ß-Estradiol Levels}

At the beginning of the experiment, there were no significant difference $(\mathrm{P}>0.05)$ in the plasma concentration of $17 \beta$-estradiol (E2) as determined for females. By the $30^{\text {th }}$ day post exposure P30M2 group that were fed $30 \mathrm{~g} / \mathrm{kg}$ of PSM had their E2 concentration declined drastically from the highest of all the treatment group on the day 0 to lower than the rest except P30M1 group which also received $30 \mathrm{~g} / \mathrm{kg}$ of the experimental diet. The concentration of E2 at day 30 were not statistically significant $(\mathrm{P}>0.05)$. The decline in the plasma concentration of E2 among the P30M2 group that received $30 \mathrm{~g}$ of PSM $/ \mathrm{kg}$ of BD for the whole experimental period continued on the $60^{\text {th }}$ day. However the depression in the $17 \beta$-estradiol level in P30M1 group recovered after the feeding with $30 \mathrm{PSM} \mathrm{g} / \mathrm{kg}$ diet was stopped. The lowest concentration of E2 $(2.62 \pm 0.4 \mathrm{ng} / \mathrm{mL})$ recorded for P30M2 group that were fed $30 \mathrm{~g} \mathrm{PSM} / \mathrm{kg}$ of BD was significantly lower $(\mathrm{P}<0.05)$ than $5.17 \pm 0.61 \mathrm{ng} / \mathrm{mL}$ obtained among the control group (P0M2). The $60^{\text {th }}$ day E2 concentration of the females of the control group $(\mathrm{P} 10 \mathrm{M} 2)$ was significantly $(\mathrm{P}<0.05)$ higher than those of the day 0 whereas the 60th day E2 of the females of $\mathrm{P} 30 \mathrm{M} 2$ was significantly $(\mathrm{P}<0.05)$ lower than those of day 0 as shown in Table 2.

Table 2. 17ß-estradiol plasma levels (mean $\pm \mathrm{SE}$ ) of $O$. mossambicus that received a basal diet supplemented with pawpaw seed meal for 30 days, and 60 days

\begin{tabular}{|c|c|c|c|c|c|c|}
\hline \multirow{2}{*}{ Treatment } & \multicolumn{2}{|c|}{ Day 0} & \multicolumn{2}{|c|}{ Day 30} & \multicolumn{2}{|c|}{ Day 60} \\
\hline & Male & Female & Male & Female & Male & Female \\
\hline P0M2 & $2.25 \pm 0.92$ & $3.17^{b c} \pm 1.08$ & $2.76 \pm 0.77$ & $4.89 \pm 0.81$ & $2.17 \pm 0.55$ & $5.17^{\mathrm{a}} \pm 0.61$ \\
\hline P10M1 & $2.26 \pm 0.92$ & $2.43 \pm 0.53$ & $1.69 \pm 0.88$ & $4.75 \pm 1.11$ & $2.42 \pm 0.52$ & $4.87^{\mathrm{ab}} \pm 0.81$ \\
\hline P30M1 & $2.02 \pm 0.82$ & $2.44 \pm 0.24$ & $2.16 \pm 0.77$ & $2.1 \pm 0.45$ & $2.09 \pm 0.55$ & $4.61^{\mathrm{ab}} \pm 0.85$ \\
\hline P10M2 & $2.15 \pm 0.75$ & $2.55 \pm 0.31$ & $2.15 \pm 0.82$ & $4.03 \pm 0.86$ & $2.72 \pm 0.59$ & $3.51^{\mathrm{ab}} \pm 0.58$ \\
\hline P30M2 & $2.62 \pm 0.92$ & $3.44^{\mathrm{c}} \pm 0.31$ & $2.54 \pm 0.82$ & $2.95 \pm 0.57$ & $1.90 \pm 0.52$ & $2.62^{\mathrm{b}} \pm 0.4$ \\
\hline
\end{tabular}

Note. Columns and rows with different superscripts differ significantly $(\mathrm{P}<0.05)$.

On the $60^{\text {th }}$ day, the E2 concentrations of the males were significantly lower than those of the females in the same treatment group. Among the males, the trend of E2 concentration in the plasma was not well defined. At the end of the experimental period, there was no significant difference $(\mathrm{P}<0.05)$ of E2 among the males of different treatment groups (Figure 1). 


\section{Estradiol 17- $\beta$ at Day 60}

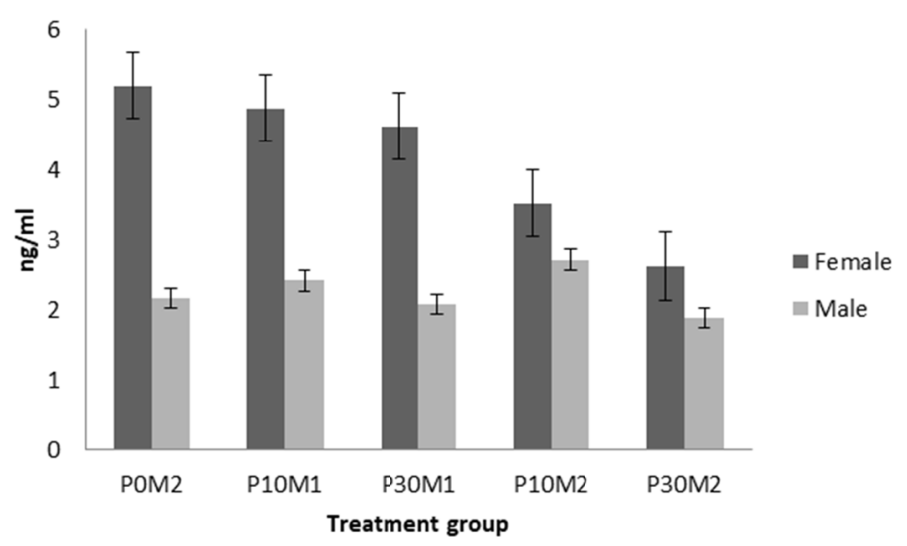

Figure 1. Estradiol-17 $\beta$ Concentration in male and female O. mossambicus fed graded levels of pawpaw seed meal at day 60

\subsection{Influence of Pawpaw Seed Meal on Serum 11-Ketotestosterone Levels}

There were no definite trends established in 11-ketotestosterone (11-KT) concentration in both male and female O. mossambicus in this study that can be attributed to the experimental diet. There was no significant difference in the concentration of $11-\mathrm{KT}$ between the different treatment groups on $30^{\text {th }}$ day however on $60^{\text {th }}$ day post exposure recorded P10M2 significantly higher than that of P10M1 and P30M1 $(\mathrm{P}<0.05)$. The same pattern recorded for the males were also obtained among the females with no significant difference $(\mathrm{P}>0.05)$ in the plasma level of 11-KT during the three sampling days (Table 3).

Table 3. Plasma concentration (Mean $\pm \mathrm{SE}$ ) of 11-Ketotestosterone (ng/mL) in male and female O. mossambicus fed graded levels of pawpaw seed meal

\begin{tabular}{|c|c|c|c|c|c|c|}
\hline \multirow{2}{*}{ Treatment } & \multicolumn{2}{|c|}{ Day 0} & \multicolumn{2}{|c|}{ Day 30} & \multicolumn{2}{|c|}{ Day 60} \\
\hline & Male & Female & Male & Female & Male & Female \\
\hline P0M2 & $0.55 \pm 0.76$ & $1.41 \pm 0.85$ & $4.11 \pm 0.81$ & $4.27 \pm 0.88$ & $0.68^{\mathrm{a}, \mathrm{b}} \pm 0.16$ & $0.23 \pm 0.18$ \\
\hline P10M1 & $1.16 \pm 0.7$ & $2.29 \pm 0.76$ & $2.43 \pm 0.81$ & $5.0 \pm 1.00$ & $0.49^{b} \pm 0.16$ & $0.22 \pm 0.18$ \\
\hline P30M1 & $2.74 \pm 0.76$ & $1.34 \pm 0.76$ & $1.23 \pm 0.75$ & $2.04 \pm 0.88$ & $0.48^{\mathrm{b}} \pm 0.15$ & $0.27 \pm 0.17$ \\
\hline P10M2 & $0.79 \pm 0.85$ & $1.84 \pm 0.85$ & $2.35 \pm 0.88$ & $2.09 \pm 0.81$ & $1.31^{\mathrm{a}} \pm 0.16$ & $0.32 \pm 0.18$ \\
\hline P30M2 & $1.39 \pm 0.65$ & $0.61 \pm 0.7$ & $2.25 \pm 0.81$ & $3.47 \pm 0.99$ & $0.91^{\mathrm{a}, \mathrm{b}} \pm 0.16$ & $0.21 \pm 0.15$ \\
\hline
\end{tabular}

Note. ${ }^{\mathrm{a}},{ }^{\mathrm{b}}$ Columns with different superscripts differ significantly $(\mathrm{P}<0.05)$.

\subsection{Influence of Pawpaw Seed Meal on Reproductive Parameters}

Data for mean gonad weight, gonadosomatic index (GSI), absolute fecundity, relative fecundity and egg diameter from $O$. mossambicus exposed to different inclusion levels of pawpaw seed meal obtained at the end of 60 days experimental period are presented in Table 4 . There were no significant differences $(P<0.05)$ in the mean gonad weight and GSI of males between the different treatment groups. In the females however the control group had a significantly $(\mathrm{P}<0.05)$ higher gonad weight when compared with those of group $\mathrm{P} 30 \mathrm{M} 2$ that were fed $30 \mathrm{~g} / \mathrm{kg}$ of PSM for 60 days, P30M1 group fed $30 \mathrm{~g} / \mathrm{kg}$ for the first 30 days and P10M2 that were fed $10 \mathrm{~g} / \mathrm{kg}$ for 60 days. The control group also recorded a significantly $(\mathrm{P}<0.05)$ higher GSI, absolute fecundity, relative fecundity and egg diameter compared to the treatment groups P30M2, P30M1 and P10M2 (Table 4). 
Table 4. Reproductive parameters (Mean $\pm \mathrm{SE}$ ) of $O$. mossambicus of different treatment groups fed graded levels of pawpaw seed meal for 60 days

\begin{tabular}{|c|c|c|c|c|c|c|c|}
\hline \multirow{2}{*}{ Treatment } & \multicolumn{2}{|c|}{ Gonad weight (g) } & \multicolumn{2}{|c|}{ Gonadosomatic index } & \multirow{2}{*}{$\begin{array}{l}\text { Absolute } \\
\text { Fecundity (egg) }\end{array}$} & \multirow{2}{*}{$\begin{array}{l}\text { Relative } \\
\text { Fecundity }\end{array}$} & \multirow{2}{*}{$\begin{array}{l}\text { Egg Diameter } \\
(\mathrm{mm})\end{array}$} \\
\hline & Male & Female & Male & Female & & & \\
\hline P0M2 & $0.47 \pm 0.1$ & $2.41^{\mathrm{a}} \pm 0.1$ & $0.5 \pm 0.2$ & $4.95^{\mathrm{a}} \pm 0.2$ & $164.6^{\mathrm{a}} \pm 9.2$ & $3.4^{\mathrm{a}} \pm 0.1$ & $1.56^{\mathrm{a}} \pm 0.1$ \\
\hline P10M1 & $0.45 \pm 0.1$ & $2.15^{\mathrm{a}, \mathrm{b}} \pm 0.1$ & $0.49 \pm 0.2$ & $4.62^{\mathrm{a}, \mathrm{b}} \pm 0.2$ & $162.4^{\mathrm{a}} \pm 9.7$ & $3.5 \pm 0.1$ & $1.53^{\mathrm{a}, \mathrm{b}} \pm 0.1$ \\
\hline P30M1 & $0.42 \pm 0.2$ & $1.63^{\mathrm{b}} \pm 0.1$ & $0.42 \pm 0.2$ & $3.63^{\mathrm{b}, \mathrm{c}} \pm 0.1$ & $110.3^{\mathrm{b}} \pm 8.6$ & $2.4^{\mathrm{b}} \pm 0.1$ & $1.19^{\mathrm{b}, \mathrm{c}} \pm 0.2$ \\
\hline P10M2 & $0.41 \pm 0.2$ & $1.72^{\mathrm{b}} \pm 0.1$ & $0.43 \pm 0.2$ & $3.42^{\mathrm{b}, \mathrm{c}} \pm 0.1$ & $118^{\mathrm{b}} \pm 9.4$ & $2.6^{\mathrm{b}} \pm 0.2$ & $1.2^{\mathrm{b}, \mathrm{c}} \pm 0.2$ \\
\hline P30M2 & $0.42 \pm 0.1$ & $1.58^{\mathrm{b}} \pm 0.1$ & $0.4 \pm 0.2$ & $3.34^{\mathrm{c}} \pm 0.2$ & $99.1^{\mathrm{b}} \pm 9.2$ & $2.2^{\mathrm{b}} \pm 0.1$ & $1.16^{\mathrm{c}} \pm 0.1$ \\
\hline
\end{tabular}

Note. ${ }^{\mathrm{a}, \mathrm{b}, \mathrm{c}}$ Columns with different superscripts differ significantly $(\mathrm{P}<0.05)$.

\section{Discussion}

\subsection{Morphometric Parameters}

It can be deduced from the result of the study that pawpaw seed meal has no effect on the morphometric parameters and specific growth rate (SGR) of $O$. mossambicus juveniles. There were high survival rate in all the treatment groups which shows that the diet has no impact on the growth and survival rate at an inclusion used in this study. This result is consistent with earlier findings of Ampofo-Yeboah (2013) who reported no significant difference in the total length, weight and body depth of $O$. mossambicus fed pawpaw see meal. The insignificant differences in the weight and other morphometric parameters observed in this study was also in agreement with previous studies conducted on the use of pawpaw seed extracts as reproductive inhibitor in laboratory animals such as albino rats (Lohiya et al., 1994).

\subsection{The Influence of PSM on 17ק-Estradiol Levels}

The availability of ELISA and other immunoassays for the quantitative determination of fish reproductive hormones (Nash et al., 2000) has made possible investigations of the variation in plasma sex steroid levels in relation to season (Cornish, 1998), pollutants (Hintemann et al., 2006) and response to xenobiotic treatments (Arukwe et al., 1999). The rate of secretion of hormone from the gland and gonad and its rate of clearance determines its concentration in the plasma. During vitellogenesis an increase in plasma levels of estrogen mainly $17 \beta$-estradiol has been found to correlate with the growth of vitellogenic oocytes (Yaron \& Levavi-Sivan, 2011). At the start of the experiment, the levels of the sex steroids measured at day zero were similar for all the treatment groups. In the females however, after the 30 day feeding with the PSM the sex steroids in treated groups were lower than the control group.

The decrease in the plasma concentration of $17 \beta$-estradiol among the group that received $30 \mathrm{~g} / \mathrm{kg}$ pawpaw seed meal for the whole experimental period continued on the $60^{\text {th }}$ day. The fact that $17 \beta$-estradiol concentration started rising again after the cessation of treatment in group P30M1 indicates reversibility of the effect of the pawpaw seed meal on $O$. mossambicus. This is in agreement with the reports of other workers who reported induction of reversible sterility in laboratory rats by the use of pawpaw seed meal (Lohiya et al., 1994; Pathak et al., 2000). The concentration of $17 \beta$-estradiol recorded for the group that were fed $30 \mathrm{~g} / \mathrm{kg}$ pawpaw seed meal for 60 days was significantly lower $(\mathrm{P}<0.05)$ than that of the control group. The fact that pawpaw seed meal resulted in lower 17ß-estradiol levels in females may explain the sex reversal of genetic females to phenotypic males of O. mossambicus attributed to the seed meal (Ampofo-Yeboah, 2013), and may also account for the inhibition of reproductive activities reported by Hossam and Wafaa (2011), and Abdelhak et al. (2013). It has been suggested that phytoestrogens exhibit an estrogenic or anti-estrogenic effect in the presence of endogenous oestrogens, i.e. they can mimic the effect of oestrogen or block the function of oestrogen (Clotfelter \& Rodriguez, 2006). This inhibition of the function of the endogenous oestrogen may explain the mode of action of pawpaw seeds in depressing the plasma levels of oestrogens in female $O$. mossambicus reported in this study. Jaiswal and Singh (2008) opined that the efficacy and or toxicity of the pawpaw seed depend on the dose and duration of the application. The concentrations of $17 \beta$-estradiol in males were significantly lower $(p>0.05)$ than in the females among all the treatment groups (Figure 1), and this was expected since the hormone play major role in oogonia proliferation and final oocytes maturation in female fish (Yaron \& Levavi-Sivan, 2011).

\subsection{Influence of Pawpaw Seed Meal on Serum 11-Ketotestosterone Levels}

Testosterone and 11-ketotestosterone are the main androgens found in fish, however 11-ketotestosterone is always quantitatively more than testosterone (Ribeiro et al., 2012). In teleost, testosterone is converted to a more 
potent androgen, 11-ketotestosterone by the hydroxylation enzyme P450 dehydrogenase (Yaron \&Levavi-Sivan, 2011). In terms of masculinization, 11-ketotestosterone is considered as one of the main mediators of masculinization and is produced early during testicular development (Blasco et al., 2012). In this study, there were no definite trends established in 11-ketotestosterone concentration in both the male and female $O$. mossambicus that can be attributed to the experimental diet. Also there was no significant difference observed when concentrations among different groups were compared.

\subsection{Influence of Pawpaw Seed Meal on Reproductive Parameters}

Gonad weight and gonadosomatic index (GSI) are indicators of gonadal maturation in fish. The GSI represents the relationship between the gonad weight and body weight, and is more suitable than absolute gonad weight as an indicator of maturity in male fish (Höerstgen-Schwark \& Langholz, 1998). The GSI of male O. mossambicus varies between 0.35 to $0.92 \%$ (Shubha \& Reddy, 2011). According to Bhatta et al. (2012) male O. mossambicus usually have their highest GSI of up to $1 \%$ of the body weight during the spawning season. In the males, there was no significant difference in the end point indicators of reproductive impairment, GSI and gonad weight recorded in this study. This observation seemed to agree with the findings of Abdelhak et al. (2013). Ampofo-Yeboah (2013) recorded no influence of $C$. papaya on the GSI of male O. mossambicus. However, in the laboratory animal research, there are conflicting reports on the effect of pawpaw seed on gonad weights. Lohiya et al. (1994) reported a reduced testicular weight in male rats while Pathak et al. (2000) reported no effect of the pawpaw seed on the weight of testis but recorded decreased sperm count, motility and viability of the spermatozoa.

In the females, the end point indicators of reproductive impairment such as gonad weight and GSI were all significantly reduced in the pawpaw seed treated groups (Table 4). This is also in agreement with the work of Abdelhak et al. (2013), who recorded significant reduction in GSI of O. niloticus fed diet containing PSM. Fecundity and survival rate are the main factors that determine the population size of fish (Campos-Mendoza et al., 2004). In this study there was significant $(\mathrm{P}<0.05)$ reduction in fecundity and oocytes diameter in the pawpaw seed treated group compared with the control as shown in table 4. There are conflicting reports on the actual fecundity of $O$. mossambicus, Mohamed et al. (2013) reported that fecundity of $O$. mossambicus range between 488 and 1368 while (Coward \& Bromage, 2000) stated that the fecundity of $O$. mossambicus can be less than 350 eggs. Blay (1981) reported on the fecundity of a related species, Sarotherodon galilaeus, to vary between 69 and 302, with a mean of 149 eggs.

During the last sampling, hatchlings/fry were observed in all the tanks that housed the control fish whereas none was observed in the tanks which housed the groups fed $30 \mathrm{~g} / \mathrm{kg}$ and those that received $10 \mathrm{~g} / \mathrm{kg}$ for the whole experimental period of 60 days. The explanation for this observation is that the pawpaw seed meal may have affected the gonadal maturation and or reproductive potential of the treated fish to the extent that there were no reproductive activities taking place. The fact that those fed $10 \mathrm{~g}$ of PSM $/ \mathrm{kg}$ of $\mathrm{BD}$ for the first 30 day recorded breeding activities while their counterparts fed the same $10 \mathrm{~g}$ of PSM for the whole 60 days did not breed proves that they may have recovered from reproductive inhibition after withdrawal of treatment. This observation was in agreement with the reports of earlier workers that pawpaw seed induced reproductive inhibitions are reversible (Pathak et al., 2000; Hossam \& Wafaa, 2011; Abdelhak et al., 2013).

\section{Conclusions}

It was found in this study that the levels of the female $17 \beta$-estradiol hormone were depressed by the addition of pawpaw seed meal in the diet of $O$. mossambicus while 11-ketotestosterone was not affected. It also inhibited reproductive activities in treated groups without untoward effect on growth and survival of the fish. It is clear from the results presented in this study that pawpaw seed meal are suitable for use in $O$. mossambicus culture as a source of control for indiscriminate spawning and overcrowding for juveniles fish, up to a concentration of 30 $\mathrm{g} / \mathrm{kg}$.

\section{Acknowledgements}

The authors express their appreciation to Stellenbosch University, Western Cape, South Africa for providing the facilities used for the study. Also sincere thanks to the West African Agricultural Productivity Program (WAAPP-Nigeria) for providing the funding.

\section{References}

Abdelhak, E. M., Madkour, F. F., Ibrahim, A. M., Sharaf, S. M., Sharaf, M. M., \& Mohammed, D. A. (2013). Effect of pawpaw (Carica papaya) seeds meal on the reproductive performance and histological characters of gonads in Nile tilapia (Oreochromis niloticus). Indian J. Appl. Res., 4(2), 34-37. https://doi.org/10.15373/ 


\section{X/DEC2013/177}

Ampofo-Yeboah, A. (2013). Effect of phytogenic feed additives on gonadal development in Mozambique tilapia (Oreochromis mossambicus) (PhD Thesis, Stellenbosch University, South Africa).

Arukwe, A., Grotmol, T., Haugen, T. B., Knudsen, F. R., \& Goksøyr, A. (1999). Fish model for assessing the in vivo estrogenic potency of the mycotoxin zearalenone and its metabolites. The Sci. Total Environ., 236, 153-161. https://doi.org/10.1016/s0048-9697(99)00275-2

Bahrami Babahydari, S., Dorafshan, S., Heyrati, F. P., \& Soofiani, N. M. (2014). The physiological changes, growth performance and whole body composition ofcCommon carp, Cyprinus carpio fed on diet containing wood betony, Stachys lavandulifolia extract. J. Agr. Sci. Tech., 16, 1565-1574.

Beardmore, J. A., Mair, G. C., \& Lewis, R. I. (2001). Monosex male production in finfish as exemplified by tilapia: Applications, problems, \& prospects. Aquacult, 197, 283-301. https://doi.org/10.1016/S0044-84 86(01)00590-7

Bhatta, S., Iwai, T., Miura, T., Higuchi, M., \& Maugars, G. (2012). Differences between male and female growth and sexual maturation in tilapia (Oreochromis mossambicus). Kathmandu University J. Sci. Eng. Tech., 8(II), $57-65$.

Blasco, M., Somoza, M. G., \& Vizziano-Cantonnet, D. (2012). Presence of 11-ketotestosterone in pre-differentiated male gonads of Odontesthes bonariensis. Fish Physiol. Biochem., 39(1), 71-74. https://doi.org/10.1007/s10695-012-9651-z

Blay, J. (1981). Fecundity and spawning frequency of Sarotherodon galilaeus in a concrete Pond. Aquacult, 25, 95-99. https://doi.org/10.1016/0044-8486(81)90103-4

Campos-mendoza, A., Mcandrew, B. J., Coward, K., \& Bromage, N. (2004). Reproductive response of Nile tilapia (Oreochromis niloticus) to photoperiodic manipulation: Effects on spawning periodicity, fecundity and egg size. Aquacult, 231, 299-314. https://doi.org/10.1016/j.aquaculture.2003.10.023

Casanova-Nakayama, A., Wenger, M., Burki, R., Eppler, E., Krasnov, A., \& Segner, H. (2011). Endocrine disrupting compounds: Can they target the immune system of fish? Marine Pollut. Bull., 63(5-12), 412-416. https://doi.org/10.1016/j.marpolbul.2011.05.007

Clotfelter, E. D., \& Rodriguez, A. C. (2006). Behavioral changes in fish exposed to phytoestrogens. Environ. Pollut, 144(3), 833-839. https://doi.org/10.1016/j.envpol.2006.02.007

Cornish, D. A. (1998). Seasonal steroid hormone profiles in plasma and gonads of the tilapia, Oreochromis mossambicus. Water SA., 24(3), 257-264.

Coward, K.. \& Bromage, N. R. (2000). Reproductive physiology of female tilapia broodstock. Rev. Fish Bio. Fish., 10, 1-25. https://doi.org/10.1023/A:1008942318272

Dang, Z., Li, K., Yin, H., Hakkert, B., \& Vermeire, T. (2011). Endpoint sensitivity in fish endocrine disruption assays: Regulatory implications. Toxicol. Letters, 202(1), 36-46. https://doi.org/10.1016/j.toxlet.2011.01.016

Desprez, D., Géraz, E., Hoareau, M. C., Mélard, C., Bosc, P., \& Baroiller, J. F. (2003). Production of a high

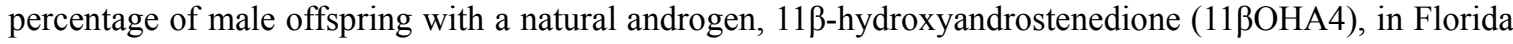
red tilapia. Aquacult, 216, 55-65. https://doi.org/10.1016/S0044-8486(02)00276-4

Höerstgen-schwark, G., \& Langholz, H. J. (1998). Prospects of selecting for late maturity in tilapia (Oreochromis niloticus) III. A selection experiment under laboratory conditions. Aquacult, 167, 123-133. https://doi.org/10.1016/0044-8486(89)90195-6

Hintemann, T., Schneider, C., Schöler, H. F., \& Schneider, R. J. (2006). Field study using two immunoassays for the determination of estradiol and ethinylestradiol in the aquatic environment. Water Res, 40(12), 2287-2294. https://doi.org/10.1016/j.watres.2006.04.028

Hossam, A. H., \& Wafaa, A. T. (2011). Assessment study on the use of pawpaw; Carica papaya seeds to control Oreochromis niloticus Breeding. Pak. J. Bio. Sci., 14, 1117-1123. https://doi.org/10.3923/pjbs.2011.111 7.1123

Jaiswal, P., \& Singh, D. K. (2008). Molluscicidal activity of Carica papaya and Areca catechu against the freshwater snail Lymnaea acuminata. Vet. Parasitol, 152(3), 264-270. https://doi.org/10.1016/j.vetpar. 2007.12.033

Lohiya, N., Goyal, R., Jayaprakash, D., Ansari, A., \& Sharma, M. (1994). Antifertility effects of aqueous extract 
of Carica papaya seeds in male rats. Plant Med., 60(5), 400-404. https://doi.org/10.1055/s-2006-959518

Lovshina, L. L., Silvab, A. B. D., \& Melob, F. R. (1990). Effects of Oreochromis niloticus females on the growth and yield of male hybrids (O. niloticus female $\times$ O. hornorum male) cultured in earthen ponds. Aquacult, 88 , 55-60. https://doi.org/10.1016/0044-8486(90)90318-H

Maranho, L. A., Botelho, R. G., Mitie Inafuku, M., de Nogueira, L., Alves de Olinda, R., Inácio de Sousa, B. A., \& Tornisielo, V. L. (2014). Testing the Neem biopesticide (Azadirachta indica A. Juss) for acute toxicity with Danio rerio and for chronic toxicity with Daphnia magna. J. Agr. Sci. Tech., 16(1), 105-111.

Mohamed, A. H., Traifalgar, R. F. M., \& Serrano, A. E. (2013). Maternal size affects fecundity of saline-tolerant tilapia Oreochromis mossambicus (Peters) in freshwater tanks. Annals Bio. Res., 4(3), 138-142.

Nash, J. P., Davail-Cuisset, B., Bhattacharyya, S., Suter, H. C., Le Menn, F., \& Kime, D. E. (2000). An enzyme linked immunosorbant assay (ELISA) for testosterone, estradiol, and 17, 20ß-dihydroxy-4-pregenen-3-one using acetylcholinesterase as tracer: Application to measurement of diel patterns in rainbow trout (Oncorhynchus mykiss). Fish Physiol. Biochem., 22(4), 355-363._https://doi.org/10.1023/A:1007850014021

Pathak, N., Mishra, P., Manivannan, B., \& Lohiya, N. K. (2000). Sterility due to inhibition of sperm motility by oral administration of benzene chromatographic fraction of the chloroform extract of the seed of Carica papaya in rats. Phytomed, 7(4), 325-333. https://doi.org/10.1016/S0944-7113(00)80051-3

Rearick, D. C., Fleischhacker, N. T., Kelly, M. M., Arnold, W. A., Novak, P. J., \& Schoenfuss, H. L. (2014). Phytoestrogens in the environment, I: Occurrence and exposure effects on fathead minnows. Environ. Toxicol. Chem, 33(3), 553-559. https://doi.org/10.1002/etc.2461

Ribeiro, C., Urbatzka, R., Castro, L. F. C., Carrola, J., Fontainhas-Fernandes, A., Monteiro, R. A. F., Rocha, E., \& Rocha, M. J. (2012). In vitro exposure of Nile tilapia (Oreochromis niloticus) testis to estrogenic endocrine disrupting chemicals: mRNA expression of genes encoding steroidogenic enzymes. Toxicol. Mech. Meth., 22(1), 47-53. https://doi.org/10.3109/15376516.2011.593053

Shubha, M., \& Reddy, S. R. (2011). Effect of stocking density on growth, maturity, fecundity, reproductive behaviour and fry production in the mouth brooding cichlid Oreochromis mossambicus. Afr. J. Biotechnol., 10(48), 9922-9930. https://doi.org/10.5897/AJB11.697

Yaron, Z., \& Levavi-Sivan, B. (2011). Endocrine regulation of fish reproduction. In A. P. Farrell (Ed.), Encyclopedia of fish physiology: From Genome to Environment (Vol. 2). San Diego: Elsevier Inc. https://doi.org/10.1016/B978-0-12-374553-8.00058-7

\section{Copyrights}

Copyright for this article is retained by the author(s), with first publication rights granted to the journal.

This is an open-access article distributed under the terms and conditions of the Creative Commons Attribution license (http://creativecommons.org/licenses/by/4.0/). 